\title{
Calibration of X-ray Diffraction Measurements for Depth-selective Structural Analysis of Two-layer Samples
}

\author{
S.N. Danilchenko ${ }^{1, *}$, O.V. Kochenko ${ }^{1}$, A.N. Kalinkevich ${ }^{1}$, A.O. Stepanenko², Ye.I. Zinchenko1, \\ P.S. Danylchenko ${ }^{3}$, I.Yu. Protsenko²
}

${ }^{1}$ Institute of Applied Physics, NASU, 58, Petropavlivska St., 40000 Sumy, Ukraine

2 Sumy State University, 2, Rymsky-Korsakov St., 40007 Sumy, Ukraine

${ }^{3}$ Institute of Physics, Faculty of Science, P.J. Šafárik University, 9, Park Angelinum, 04154 Košice, Slovak Republic

(Received 24 February 2021; revised manuscript received 15 April 2021; published online 20 April 2021)

\begin{abstract}
In the metal structures that are subjected to significant mechanical and radiation loads during their operation, structural alterations occur, which are unevenly distributed over the depth of the material. Materials with a modified surface, including thin coatings and multilayers, are equally challenging objects for structural studies. The development of methods for depth-selective layer-by-layer X-ray diffraction diagnostics is a nontrivial task aimed at controlling the effective depth of the collection of structural information. The most developed approaches to date include: (a) asymmetric (glancing-angle) geometry and (b) the use of primary radiation with different penetrating power. In both cases, calibration procedures with coatings or two-layer systems of known thickness are required to determine the thickness of an effectively reflective layer. In this work, we have studied the possibilities of X-ray diffraction examinations of steel and iron samples with a thin (micron) copper coating. The thickness of the copper coating was estimated from the intensity decrease of the iron substrate's diffraction lines. With the use of asymmetric (glancingincidence) measurements, the conditions for the disappearance of lines from the substrate were established, which made it possible to estimate with acceptable accuracy the thickness of the steel layer participating in the formation of the diffraction pattern. The method of the depth-differentiated estimation of the structural characteristics of the "interface" and conditionally "bulk" regions of the $\alpha$-Fe substrate by using polychromatic cobalt radiation is tested. The limitations of this approach and the possibility of its application to a wider range of steels are discussed. The considered aspects of X-ray diffraction studies of model systems of the "steel-coating" or "steel-modified surface" type are important in the study of surface radiation-stimulated structural alterations in steels of power engineering.
\end{abstract}

Keywords: X-ray diffraction, Radiation absorption, X-ray penetration depth, Steel, Coating, Copper, Glancing-incidence geometry, Polychromatic radiation.

\section{INTRODUCTION}

Steels of various structural classes are widely used in power engineering, including constructions exposed to radiation [1,2]. Neutron beams generated in both fusion reactors and fission reactors provoke structural alterations in materials, leading to their serious destructive changes during long-term operation. Beams of accelerated particles (protons, ions of helium and heavy elements) are used in simulation experiments aimed at predicting the safe life of reactor materials. One of the disadvantages of such experimental modeling is that the structural defects formed by ion irradiation, in contrast to the defects of neutron generation, are not formed in the entire volume of the material, but only in its near-surface regions determined by the energy of the bombarding particles [2]. Under these conditions, the role of surface analysis methods increases, which makes it possible to carry out depth-selective structural diagnostics with the profiling of the informative depth and the determination of the levels of predominant occurrence of defects formed by irradiation. In X-ray diffraction studies, a special "glancing-angle" geometry and/or long-wave (soft) primary radiation are used to controllably reduce the depth of structural information collection [3-5].

To estimate the depth of the layer of the material participating in the formation of the diffraction pattern (briefly, "effective penetration depth", $\tau$ ), in the symmetric Bragg-Brentano $(\theta-2 \theta)$ geometry (Fig. 1), an equation is usually used, which is a consequence of the exponential law of radiation absorption in matter [3, 4]:

$$
\tau=\ln \left(I_{0} / I_{\tau}\right) \frac{\sin \theta}{(2 \mu / \rho) \cdot \rho}
$$

where $\mu / \rho$ is the mass attenuation coefficient of radiation, which is, in fact, the total integral cross-section of interaction (photoabsorption cross-section), $\rho$ is the density of the sample material, $\theta$ is the angle between the sample surface and the direction of the primary beam, or half the diffraction angle, $I_{0}$ is the intensity of the primary (incident) beam, $I_{\tau}$ is the recorded intensity of the beam "reflected" from the $h k l$ planes located within the depth of the "reflecting" layer $\tau$.

The $I_{0} / I_{\tau}$ ratio is to a large degree determined by instrumental factors and, first of all, by the sensitivity of the detection system of a diffractometer. The uncertainty of this ratio forces researchers in practice, when estimating $\tau$, to resort to the choice of an arbitrary $I_{0} / I_{\tau}$ or to use a series of values of $\tau$ for different $I_{0} / I_{\tau}$ [5]. For example, the authors of [4] take $I_{0} / I_{\tau}=20$, while in [6] $I_{0} / I_{\tau}=2$. It is supposed that in the first case, the diffrac-

\footnotetext{
*danilserg50@gmail.com
} 
tometer counter allows recording $5 \%$ of the primary beam intensity, and in the second, $50 \%$, and nothing less. As can be seen from Fig. 2, such an ambiguity in the choice of $I_{0} / I_{\tau}$ does not allow the depth of the material layer involved in the formation of the diffraction pattern to be estimated with acceptable accuracy. Such estimates differ most for large angles $2 \theta$.

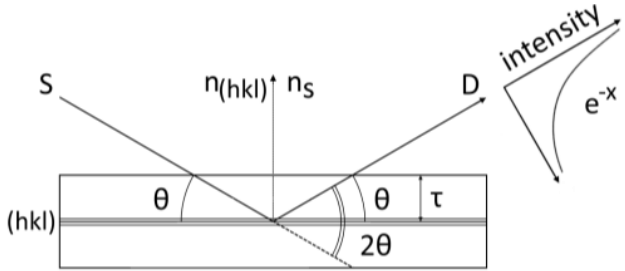

Fig. 1 - Schematic representation of the penetration depth $(\tau)$ at $\theta-2 \theta$ focusing, $S$ is the focus of the X-ray tube, $D$ is the radiation detector, $n_{(h k l)}$ and $n_{s}$ are the normals to the reflecting planes $h k l$ and to the sample surface, respectively

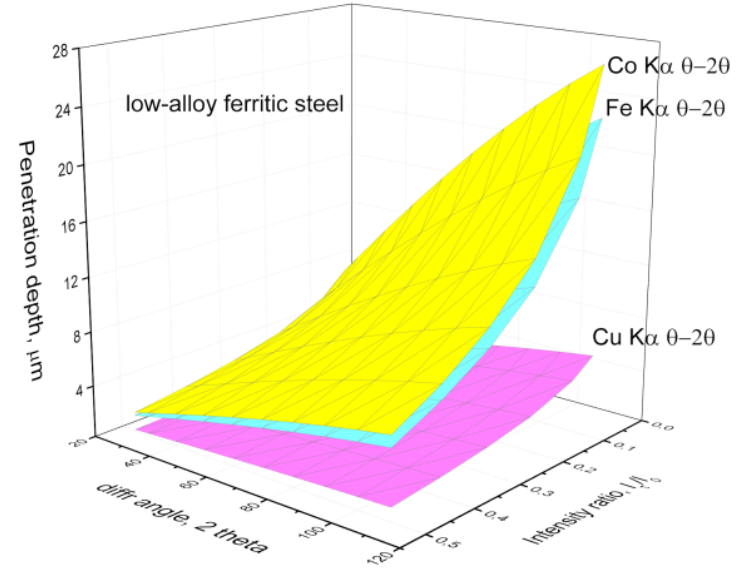

Fig. 2 - Dependence of the penetration depth on the diffraction angle $2 \theta$ and the ratio $I_{\tau} / I_{0}$ for low-alloy ferritic steel calculated by formula (1) for different probing radiation $(\mathrm{CoK} a$, $\mathrm{FeK} a, \mathrm{CuK} a)$

The purpose of this work was to refine the thickness of the layer of the material involved in the formation of the diffraction pattern, using the example of ferritic steel, by calibrating the diffractometric measurements using a copper coating of known thickness. In addition to this, the work considered the possibility of simultaneously obtaining structural information from the uppermost ("surface") and more in-depth ("bulk") layers of steel samples by using unfiltered cobalt radiation containing $\operatorname{CoK} \beta$ and $\operatorname{CoK} \alpha$ components.

\section{MATERIALS AND METHODS}

Ferritic sheet steel (thickness $2 \mathrm{~mm}$ ) with the $\mathrm{Fe}$ content of about 98.3 wt. \% was chosen as the starting material for the studies. The surface of the samples $18 \times 18 \mathrm{~mm}$ in size was carefully processed before applying the coatings with emery paper with the finest grain size (grade 2500).

The deposition of copper coatings on a steel substrate was carried out in a VUP-5M installation at a residual atmosphere gas pressure of $10^{-4} \mathrm{~Pa}$. Copper was evaporated by electrothermal (resistive) method from a tungsten boat. The deposition of coatings took place without heating the substrate.

The thickness of the coating was controlled in the process of condensation by a quartz resonator with an accuracy of $10 \%$, for which an industrial resonator of the RG-08 type and an electric oscillator with a frequency of $10 \mathrm{MHz}$ were used. According to these estimates, the thickness of the deposited copper coating on two prepared steel samples was $510 \mathrm{~nm}$ and $986 \mathrm{~nm}$.

The structural characteristics of the samples were studied by X-ray diffraction (DRON-4-07 instrument, "Burevestnik", connected to the computer-aided experiment control and data processing system). DifWin-1 software package (Etalon PTC Ltd, Russia) was used for recording diffraction patterns and their primary processing. In the work, Co radiation was used, both with a $\beta$-filter ( $\mathrm{Fe}$ foil) to suppress the $\operatorname{CoK} \beta$ component and without it. The details of the X-ray diffraction experiment are described in the article [7] and in the next section of this work.

Scanning electron microscopy images of the coating surface were obtained using a REMMA-102 device (JSC SELMI, Ukraine).

\section{RESULTS AND DISCUSSION}

Fig. 3 shows an image of the surface of the copper coating applied to steel. The coating is not perfectly smooth, and the steel substrate has distinct traces of preliminary polishing, which are not hidden by the

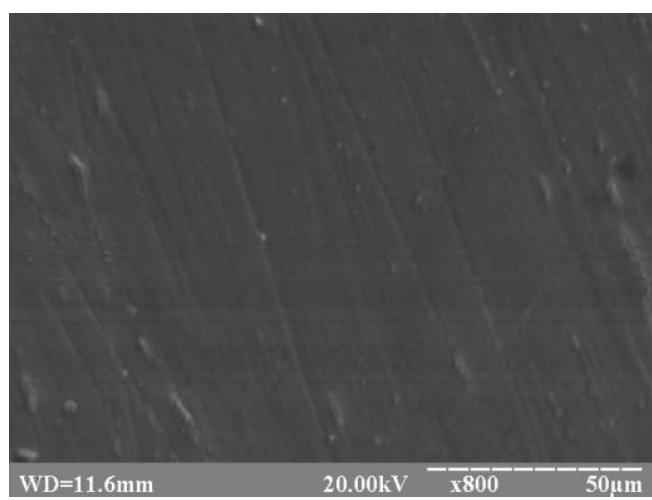

Fig. 3 - SEM image of the surface of the copper coating on a ferritic steel sample

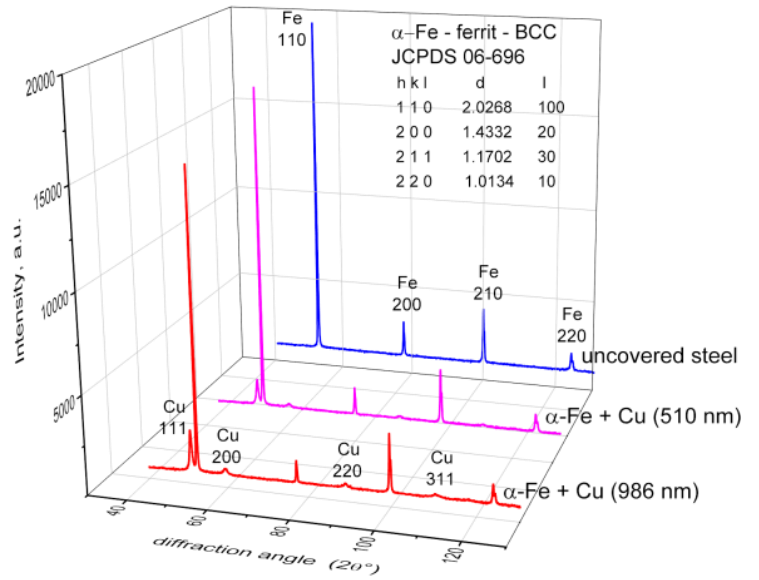

Fig. 4 - X-ray diffraction patterns of ferritic steel with copper coatings of two different thicknesses 
deposited copper layer. In general, the samples prepared for the study do not have any exclusive morphological features of the surface, which is actually required for their maximum compliance with real structural materials for nuclear power.

X-ray diffraction patterns of two samples of steel with copper coatings of different thicknesses and of uncoated steel are shown in Fig. 4. As can be seen, the phase composition of the steel corresponds to $a$-Fe (ferrite, body-centered cubic lattice, JCPDS 06-698), and the copper coating corresponds to the JCPDS 04-836 card. It can be seen from the diffraction patterns that the steel sample does not have any pronounced texture.

\subsection{Evaluation of the Thickness of the Copper Coating by Decreasing the $a$-Fe Substrate Lines Intensity}

The intensities of the $a$-Fe lines in the diffraction patterns of the samples with coatings are less than the intensity of the same lines in the diffractogram of the original (uncoated) sample (Fig. 4). This is a consequence of the effect of radiation absorption in the $\mathrm{Cu}$ layer deposited on the steel surface. To estimate the thickness of the absorbing copper layer $\left(\tau_{\mathrm{Cu}}\right)$, one can formally use equation (1) [3, 8], but the meaning of the parameters included in it (with the exception of the angle $\theta$ ) will be different in this case. Namely, $I_{\tau}$ and $I_{0}$ are the intensities of the $a$-Fe lines in diffractograms of the samples with and without coating, respectively, $\mu / \rho$ is the mass attenuation coefficient of $\mathrm{CoK} a$ radiation in $\mathrm{Cu}, \rho$ is the density of $\mathrm{Cu}$.

The results of the calculations performed using the integrated intensity of the strongest $a$-Fe (110) line gave the values of $\tau \mathrm{Cu}$ slightly less than expected (464 $\mathrm{nm}$ vs $510 \mathrm{~nm}$ and $833 \mathrm{~nm}$ vs $986 \mathrm{~nm}$ ). This can be explained by the discontinuity (porosity) of the copper coating, which leads to a decrease of the real $\mu / \rho$ and $\rho$ in comparison with the reference values [9].

However, in order to avoid confusion, in the future we will use the values of the thickness of the deposited copper coating that were obtained using a quartz resonator during the condensation process.

\subsection{Using the Glancing-incidence Geometry to Estimate the $I_{0} / I_{\tau}$ Ratio}

One of the effective ways to reduce the thickness of the material layer involved in the formation of the diffraction pattern is the use of asymmetric geometry for recording diffraction patterns with a sufficiently small (glancing) angle of incidence $(\alpha)$ of the primary beam [3-5]. The scheme of such geometry is shown in Fig. 5. To determine $\tau$ in this case, formula (2) is valid, which is the general case of formula (1), i.e. for $a=\theta$ formula (2) is identical to formula (1):

$$
\tau=\frac{\ln \left(I_{0} / I_{\tau}\right)}{(\mu / \rho) \cdot \rho} \cdot \frac{\sin \alpha \cdot \sin (2 \theta-\alpha)}{\sin \alpha+\sin (2 \theta-\alpha)} .
$$

If, in the glancing-incidence geometry, the diffraction patterns of a specimen with a coating of known thickness are recorded with a stepwise decrease in the angle $a$, then having achieved the disappearance of the diffraction lines from the substrate, it is possible to determine the ratio $I_{0} / I_{\tau}$. Fig. 6 shows the diffraction patterns of the $a$-Fe sample with copper coating $(510 \mathrm{~nm})$ recorded in asymmetric geometry (Fig. 5) at three values of the angle $a$.

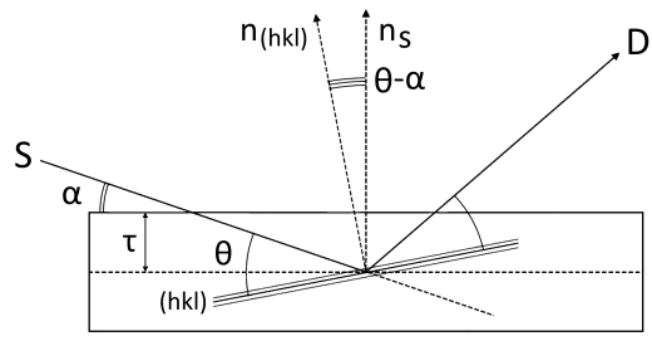

Fig. 5 - The scheme of asymmetric geometry with small angles of inclination of the primary beam $(a)$ to the plane of the sample. $S$ is the focus of the X-ray tube, $D$ is the radiation detector, $\theta$ is the half of the diffraction angle, $\theta-a$ is the angle between the normal to the reflecting planes and the normal to the sample surface

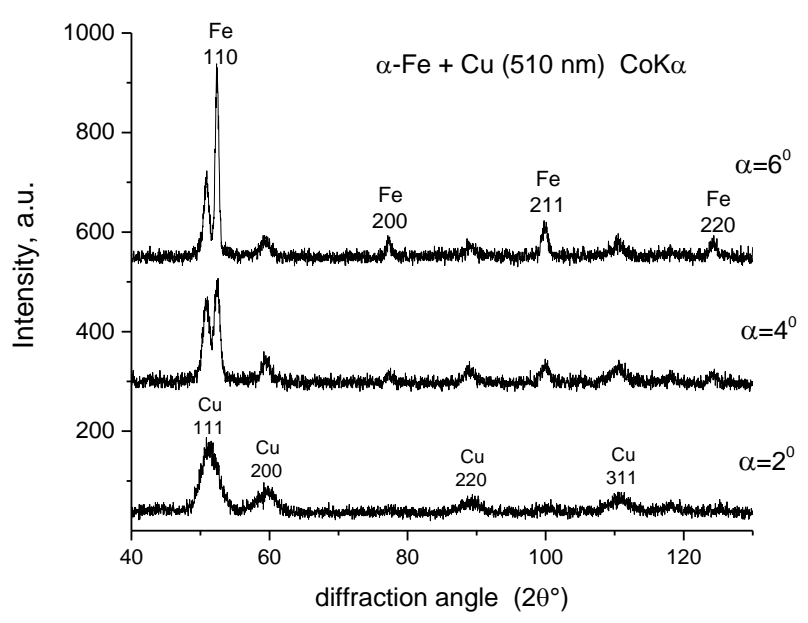

Fig. 6 - X-ray diffraction patterns of $\alpha$-Fe coated with $510 \mathrm{~nm}$ $\mathrm{Cu}$ recorded in $\mathrm{CoK} a$ radiation and with asymmetric geometry, demonstrating the effect of disappearance of the iron substrate lines at $a \leq 2$

As can be seen from Fig. 6, the iron lines disappear at $a \leq 2$, although the weak contribution of the most intense $a-\mathrm{Fe}(110)$ line to the diffuse profile of the $\mathrm{Cu}$ (111) line cannot be completely excluded. The strong broadening of $\mathrm{Cu}$ lines with decreasing $a$ is associated with the violation of the focusing conditions in the case of asymmetric geometry. Considering this uncertainty, we calculated the $I_{0} / I_{\tau}$ values using formula (2) for two grazing angles $\left(\alpha=2^{\circ}\right.$ and $\left.a=1^{\circ}\right)$ and for three diffraction lines of copper (Table 1$)$. The obtained values of $I_{0} / I_{\tau}$ strongly depend on the angle $a$ (which, as it revealed, is difficult to determine with good accuracy) and weakly depend on the diffraction angle $2 \theta$. Thus, from the performed estimates it is clear that the real ratio $I_{0} / I_{\tau}$ lies within a wide range, namely, from 2.8 to 7.7. However, even this ambiguity significantly narrows the range of the calculated values of the depth of the material layer involved in the formation of the diffraction pattern in comparison with the estimated values of $I_{0} / I_{\tau}$ used in some works (e.g., [4]). 
Table 1 - Results of the ratio $I_{0} / I_{\tau}$ calculation using formula (2) for $\alpha=2^{\circ}$ and $\alpha=1^{\circ}\left(\tau_{\mathrm{Cu}}=510 \mathrm{~nm} ; \rho_{\mathrm{Cu}}=8.96 \mathrm{~g} / \mathrm{cm}^{3}\right.$ and $\mu / \rho=76.15 \mathrm{~cm}^{2} / \mathrm{g}$ for $\mathrm{CoK} a$ radiation in $\left.\mathrm{Cu}[9]\right)$

\begin{tabular}{|l|l|l|l|}
\hline $2 \theta(h k l)$ & $50.8(111)$ & $59.42(200)$ & $89.04(220)$ \\
\hline $\ln \left(I_{0} / I_{\tau}\right)\left(\alpha=1^{\circ}\right)$ & 2.0397 & 2.035 & 2.029 \\
\hline $\ln \left(I_{0} / I_{\tau}\right)\left(\alpha=2^{\circ}\right)$ & 1.0434 & 1.0385 & 1.032 \\
\hline$I_{0} / I_{\tau}\left(\alpha=1^{\circ}\right)$ & 7.7 & 7.66 & 7.62 \\
\hline$I_{0} / I_{\tau}\left(\alpha=2^{\circ}\right)$ & 2.84 & 2.83 & 2.81 \\
\hline
\end{tabular}

3.3 Using Unfiltered Cobalt Radiation to Obtain Structural Information from "Bulk" and Near-surface Regions of Copper-coated Steel

The importance of the structural analysis of the near-surface (interface) layer of the substrate material adjacent to the applied coating stems from a number of problems associated with the mechanisms of action of coatings on the substrate surface. Copper and copper alloy coatings on steel structures are used in power engineering to improve thermal and electrical conductivity, as well as to increase corrosion resistance.

In the case of a sample with a coating or with a modified surface layer, provided its phase and concentration homogeneity, it is necessary to consider a twolevel or two-layer system that absorbs radiation (Fig. 7) and, finally, forms the resulting (averaged) diffraction pattern.

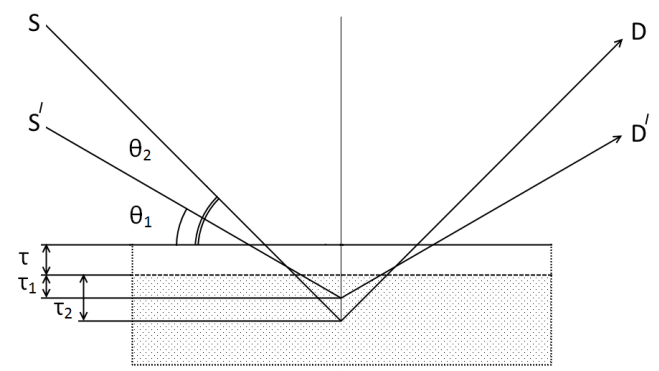

Fig. 7 - Diffraction scheme at $\theta-2 \theta$ focusing for a sample with a coating or with a modified surface layer of thickness $\tau ; \tau_{1}$ and $\tau_{2}$ are the penetration depths at different diffraction angles $\left(\theta_{1}\right.$ and $\theta_{2}$, respectively); $S$ and $S^{\prime}, D$ and $D^{\prime}$ indicate the source (tube focus) and the radiation detector at different angles $\theta$

Then, for the considered model sample (a steel plate with a copper coating), the total attenuation of X-ray radiation with a symmetric scheme of diffraction (Fig. 7) can be represented as follows:

$$
I_{\tau}=I_{0} \cdot \exp \left\{-\left[2 \frac{(\mu / \rho)_{C u} \cdot \rho_{C u} \cdot \tau_{C u}}{\sin \theta}+2 \frac{(\mu / \rho)_{\alpha F e} \cdot \rho_{\alpha F e} \cdot \tau_{\alpha F e}}{\sin \theta}\right]\right\},
$$

where $(\mu / \rho)_{\mathrm{Cu}}$ and $(\mu / \rho)_{\alpha \mathrm{Fe}}$ are the mass attenuation coefficients of X-ray radiation in $\mathrm{Cu}$ and $\alpha$-Fe, $\rho_{\mathrm{Cu}}$ and $\rho_{a \mathrm{Fe}}$ are the densities of $\mathrm{Cu}$ and $\alpha$-Fe, respectively, $\tau_{\mathrm{Cu}}$ is the thickness of the $\mathrm{Cu}$ coating, and $\tau_{a \mathrm{Fe}}$ is the thickness of the effectively reflecting steel layer. Since the additive coefficient of attenuation of X-ray radiation in a material $(\mu$ or $\mu / \rho)$ is, in fact, the total integral crosssection of interaction (photoabsorption cross-section), including elastic scattering processes, the above formula also takes into account diffraction effects. Thus, the thickness of the steel layer participating in the formation of the diffraction pattern $\left(\tau_{\alpha \mathrm{Fe}}\right)$ can be estimated by the formula:

$$
\tau_{\alpha F e}=\frac{1}{(\mu / \rho)_{\alpha F e} \cdot \rho_{\alpha F e}}\left[\ln \left(I_{0} / I_{\tau}\right) \frac{\sin \theta}{2}-(\mu / \rho)_{C u} \cdot \rho_{C u} \cdot \tau_{C u}\right]
$$

It is possible to use this formula directly to calculate $\tau_{\alpha \mathrm{Fe}}$, i.e. the thickness of the analyzed steel layer under the copper coating, having the value $I_{0} / I_{\tau}$ available. This ratio was estimated above (Table 1) as lying in the range of 2.8-7.7.

When unfiltered cobalt radiation (containing $\mathrm{CoKa}$ and $\operatorname{CoK} \beta$ ) is used for an iron or steel sample, two systems of reflections will be present in the diffractogram, corresponding to the layers of material of different thicknesses. Fig. 8 shows the diffraction pattern of $\alpha$-Fe sample with a copper coating $(510 \mathrm{~nm})$ recorded in polychromatic radiation: $\operatorname{CoK} \alpha$ plus $\operatorname{CoK} \beta$.

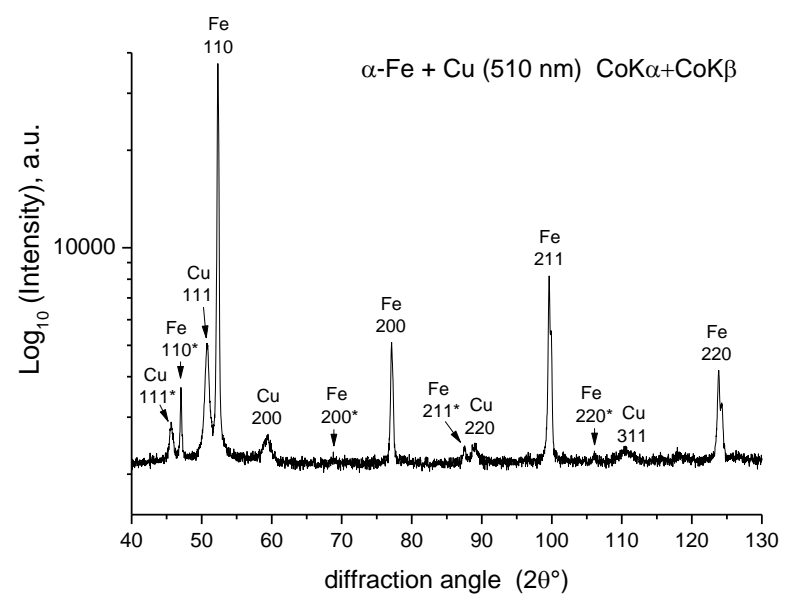

Fig. 8-X-ray diffraction pattern of $a$-Fe coated with $\mathrm{Cu}$ $(510 \mathrm{~nm})$ recorded in unfiltered (polychromatic) cobalt radiation; line intensities are presented on a logarithmic scale; indices $h k l$ marked with $\left(^{*}\right)$ refer to the diffraction of $\operatorname{CoK} \beta$ radiation

It can be seen from the presented diffraction pattern that the system of iron reflections obtained in $\operatorname{CoK} \beta$ radiation does not overlap with copper lines and can be used for independent analysis.

The different probing depths of $\operatorname{CoK} \alpha$ and $\operatorname{CoK} \beta$ radiation in an iron (or steel) sample are due to the presence of an absorption jump in the $\mu / \rho$ dependence on $\lambda$ for iron (Fig. 9). As can be seen, a jump in the absorption of radiation in iron breaks the dependence of $\mu / \rho$ on $\lambda$, so that the diffraction depth of $\mathrm{CoK} a$ radiation will be 5-6 times greater than the diffraction depth of the $\operatorname{CoK} \beta$ radiation component.

Using formula (4) to calculate $\tau_{\alpha \mathrm{Fe}}$ for two $I_{0} / I_{\tau}$ (5 and 3.33), the numerical values of the effectively reflecting layer thickness were obtained for the main diffraction lines of $\alpha$-Fe (Table 2). The selected $I_{0} / I_{\tau}$ values can be considered a reasonable compromise, since they lie within the range obtained from the previous estimates (from 2.8 to 7.7 ).

From the calculations performed under these assumptions, it follows that in the diffraction analysis of steel coated with copper $(510 \mathrm{~nm})$ for $\mathrm{CoK} a$, the penetration depth is approximately 6 to $15 \mu \mathrm{m}$, and for $\mathrm{CoK} \beta$ it is approximately $1-2 \mu \mathrm{m}$. This makes it possible to simultaneously obtain the structural information from the upper ("interfacial") and more in-depth (condi- 
tionally bulk) regions of the steel substrate using a single (cobalt) X-ray tube and constant geometrical conditions of data acquisition.

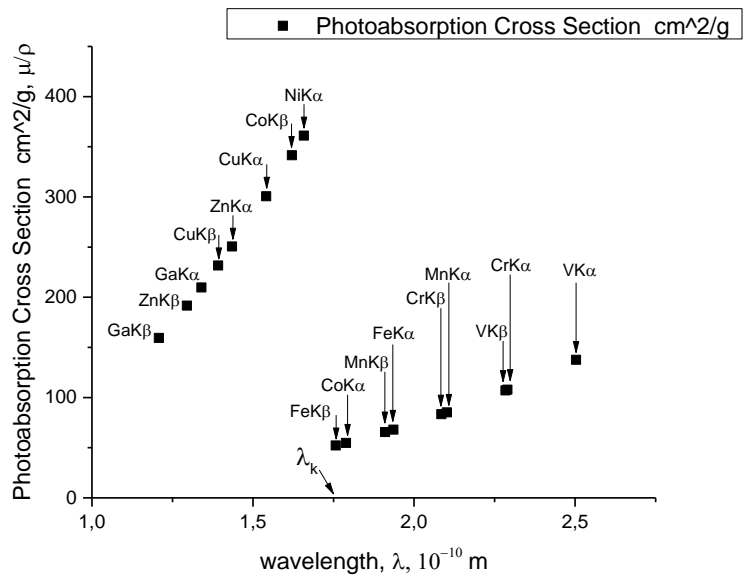

Fig. 9 - The dependence of the mass attenuation coefficient of $\mathrm{X}$-ray radiation $(\mu / \rho)$ in iron on the radiation wavelength (built on the reference data [9]); the threshold (jump) of absorption $\lambda_{k}$ corresponds to the removal of a $K$-electron from the Fe atom

Table 2 - Results of calculating $\tau_{a \mathrm{Fe}}(\mu \mathrm{m})$ for $\mathrm{CoK} \alpha$ and $\operatorname{CoK} \beta$ radiation for two values of $I_{0} / I$. Reference values for $\mathrm{Fe}$ $\mu / \rho_{(\mathrm{CoK} \beta)}=341.5 \mathrm{~cm}^{2} / \mathrm{g}$ and $\mu / \rho_{(\mathrm{CoK} a)}=54.79 \mathrm{~cm}^{2} / \mathrm{g}[9]$

\begin{tabular}{|c|l|c|c|c|c|}
\hline & \multicolumn{1}{|c|}{$h k l$} & 110 & 200 & 211 & \multicolumn{1}{c|}{220} \\
\hline \multirow{3}{*}{$\operatorname{CoK} \alpha$} & $\begin{array}{l}I_{0} / I_{\tau}=5.0 \\
\ln I_{0} / I_{\tau}=1.61\end{array}$ & 7.45 & 10.87 & 13.51 & 15.72 \\
\cline { 2 - 6 } & $\begin{array}{l}I_{0} / I_{\tau}=3.33 \\
\ln I_{0} / I_{\tau}=1.20\end{array}$ & 5.35 & 7.90 & 9.86 & 11.51 \\
\hline \multirow{2}{*}{$\operatorname{CoK} \beta$} & $\begin{array}{l}I_{0} / I_{\tau}=5.0 \\
\ln I_{0} / I_{\tau}=1.61\end{array}$ & 1.10 & 1.60 & 1.98 & 2.30 \\
\cline { 2 - 6 } & $\begin{array}{l}I_{0} / I_{\tau}=3.33 \\
\ln I_{0} / I_{\tau}=1.20\end{array}$ & 0.80 & 1.17 & 1.45 & 1.69 \\
\hline
\end{tabular}

The disadvantages of this approach include the fact that the diffraction lines obtained in $\operatorname{CoK} \beta$ radiation have insufficient analytical characteristics due to their smearing and low intensity. This limits the application of the methods of line broadening analysis, but still gives the possibility to precisely determine the lattice constant using extrapolation methods [6]. The use of Nelson-Riley extrapolation for all recorded $a$-Fe lines showed that the interface steel layer adjacent to the copper coating has a slightly larger lattice parameter than $a$-Fe layers remote from the contact surface $(2.8680 \AA$ vs $2.8674 \AA)$. For the control sample of uncoated steel, this effect was not observed. Since copper can dissolve in $\alpha$-Fe to a limited extent, it is reasonable to assume that the reason for the increase in the lattice parameter of $a$-Fe is the partial substitution of iron by copper.

From the diffraction pattern shown in Fig. 8, it can be seen that the ratio of intensities of the (111) $\mathrm{Cu}$ and (110) $\alpha$-Fe lines obtained in $\operatorname{CoK} \alpha$ and $\operatorname{CoK} \beta$ radiation differs quite significantly. Formal application of the phase ratio estimation of copper and $a$-Fe by the Reference Intensity Ratio (RIR) method [10] showed that in the case of $\mathrm{CoK} a$ radiation, the phases of $a-\mathrm{Fe}$ and $\mathrm{Cu}$ are in the ratio of $3.5: 1$, while for $\operatorname{coK} \beta$ radiation this ratio becomes approximately equal 1:1 with a slight predominance of copper. This result is in good agreement with the estimated calculations of $\tau_{\alpha} \mathrm{Fe}$ for the $\mathrm{CoK} \alpha$ and $\operatorname{CoK} \beta$ radiation components (Table 2) and clearly illustrates the possibility of depth-differentiated analysis of the near-surface layers of iron and steel samples using cobalt radiation.

From the equation for $\tau_{a \mathrm{Fe}}$ determination (4), it is possible to formulate the condition for the disappearance of diffraction lines of $a$-Fe with an increase in the copper coating thickness:

$$
\ln \left(I_{0} / I_{\tau}\right) \frac{\sin \theta}{2}=(\mu / \rho)_{C u} \cdot \rho_{C u} \cdot \tau_{C u} .
$$

According to such estimates, the (110) $a$-Fe line should disappear at a coating thickness of 4-5 $\mu \mathrm{m}$, and the (220) line at $8-10 \mu \mathrm{m}$, although in practice less intense lines corresponding to large $2 \theta$ angles weaken and disappear faster than strong lines at small $2 \theta$.

Based on the condition (5), an alternative method for determining the $I_{0} / I_{\tau}$ ratio can be implemented. If the thickness of the coating is increased stepwise and the diffraction patterns of a two-layer sample are taken, then the conditions for the disappearance of the substrate lines will correspond to the desired value of $\ln \left(I_{0} / I_{\tau}\right)$. It is clear that such a method does not have high accuracy, in view of the noted above ambiguity in determining the critical thickness of the coating; moreover, it is more laborious than the glancing-incidence technique used in this work.

It can be seen from the results obtained that an absorbing copper coating with a thickness of $2-3 \mu \mathrm{m}$ on a steel substrate does not prevent a satisfactory estimation of the depth of the steel layer involved in the formation of the diffraction pattern. Therefore, the method of analyzing the near-surface layers of steel samples using unfiltered cobalt radiation is applicable to samples coated with copper or other material with a close or lower $\mu / \rho$ value in the case of non-overlapping diffraction lines.

In the case of high-alloy steels, due to the additive nature of the X-ray attenuation coefficient in the material, it is necessary to preliminary plot the dependence of $\mu / \rho$ on $\lambda$ (Fig. 9) for a specific steel grade with the determination of the numerical values of $\mu / \rho_{(\mathrm{CoK} a)}$ and $\mu / \rho_{(\mathrm{CoK} \beta)}$.

\section{CONCLUSIONS}

On the example of ferritic steel with a copper coating, the possibility of structural analysis of the nearsurface layers of steel with separate estimation of the characteristics of the "interface" and conditionally "bulk" regions of the $a$-Fe substrate using polychromatic cobalt radiation was studied. The correctness of the estimation of the layer depth of steel participating in the formation of the diffraction pattern is ensured by the use of the glancing-incidence diffraction with the determination of the conditions of the substrate lines disappearance. The method is suitable for phase analysis and for determining the lattice constant of the near-surface regions of steel and iron samples and is limitedly suitable for 
texture analysis and analysis of diffraction line broadening. The considered aspects of X-ray diffraction studies of the model systems of the "steel-coating" or "steelmodified surface" type are useful in studies of radiation-stimulated surface structural alterations in steels of power engineering.

\section{REFERENCES}

1. T.N. Kompaniets, Probl. At. Sci. Technol., Ser. Thermonuclear fusion (PAS\&T/TF) 3, 16 (2009).

2. R.L. Vasilenko, V.N. Voyevodin, A.S. Kalchenko, Y.O. Nazarenko, M.M. Pylypenko jr., E.S. Solopikhina Probl. At. Sci. Technol. No 4(128), 3 (2020).

3. P.F. Fewster, Rep. Prog. Phys. 59 No 11, 1339 (1996).

4. Y.P. Mironov, L.L. Meisner, A.I. Lotkov, Tech. Phys. 53 No 7, 934 (2008).

5. T. Frączek, M Olejnik, M Pilarska, Archiv. Metall. Mater. 50 No 3, 2005 (2015).

6. L.I. Gladkikh, S.V. Malykhin, A.T. Pugachev, M.V. Reshetnyak, Strukturnyy analiz v fizicheskom materialovedenii (Kharkiv:

\section{ACKNOWLEDGEMENTS}

This work was partially supported by IAEA (Research Contract No 24191), as a part of Coordinated Research Project F43025, and partially supported by the National Academy of Sciences of Ukraine (state registration number of the work 0120U105445).

\title{
Калібрування рентген-дифрактометричних вимірювань для контрольованого за глибиною структурного аналізу двошарових зразків
}

\author{
С.М. Данильченко ${ }^{1}$, О.В. Коченко ${ }^{1}$, О.М. Калінкевич ${ }^{1}$, А.О. Степаненко ${ }^{2}$, Є.І. Зінченко ${ }^{1}$, \\ П.С. Данильченко ${ }^{3}$, Ю.Ю. Проценко ${ }^{2}$
}

\author{
1 Інститут прикладної бізики НАНУ, вул. Петропавлівська, 58, 40000 Сули, Украӥна \\ ${ }^{2}$ Сулський державний університет, вул. Рилського-Корсакова, 2, 40007 Сули, Украӥна \\ ${ }^{3}$ Institute of Physics, Faculty of Science, P.J. Šafárik University, 9, Park Angelinum, 04154 Košice, Slovak Republic
}

\begin{abstract}
У металевих конструкціях, які отримують при експлуатації значні механічні і радіаційні навантаження, виникають структурні альтерації, що нерівномірно розподілені по глибині матеріалу. У такій же мірі складними об'єктами структурних досліджень є і матеріали з модифікованою поверхнею, включаючи тонкі покриття і мультишари. Розвиток методів селективної за глибиною пошарової рентген-дифракційної діагностики є нетривіальним завданням, спрямованим на контроль ефективної глибини збору структурної інформації. На сьогодні найбільш розроблені підходи включають: (а) асиметричну (ковзну) геометрію та (б) застосування первинного випромінювання з різною проникаючою здатністю. В обох випадках для визначення товщини шару ефективного відбивання необхідно виконати калібрувальні процедури із використанням покриттів або двошарових систем відомої товщини. У даній роботі вивчені можливості рентгенівської дифракції для аналізу зразків сталі та заліза з тонким (мікронним) мідним покриттям. За ослабленням інтенсивності ліній підкладки заліза оцінена товщина мідного покриття. Із застосуванням несиметричної (скісної) зйомки встановлено умови зникнення ліній від підкладки, що дозволило з прийнятною точністю оцінювати товщину шару сталі, який бере участь в утворенні дифракційної картини. Апробовано метод диференціальної за глибиною оцінки структурних характеристик «інтерфейсної» і умовно «об'емної» областей підкладки $\alpha$-Fе шляхом застосування поліхроматичного кобальтового випромінювання. Обговорено обмеження апробованого підходу і можливості його застосування до більш широкого спектру сталей. Розглянуті особливості рентген-дифракційних досліджень модельних систем типу «сталь-покриття» або «сталь-модифікована поверхня» важливі при вивченні поверхневих радіаційно-стимульованих структурних альтерацій в сталях енергетичного машинобудування.
\end{abstract}

Ключові слова: Рентгенівська дифракція, Поглинання випромінювання, Товщина шару, що ефективно відбиває, Сталь, Покриття, Мідь, Ковзна геометрія, Поліхроматичне випромінювання. 